\title{
Thin-skinned thrust-fault tectonics offshore south-west Vietnam
}

\author{
Stig A. Schack Pedersen, Lars Ole Boldreel, Emil Bach Madsen, Mette Bjerkvig Filtenborg \\ and Lars Henrik Nielsen
}

In the c. $40000 \mathrm{~km}^{2}$ large Phu Quoc basin south-west of Vietnam reflection seismic data suggest a thin-skinned thrust-fault complex concealed by Neogene marine sediments (Fig. 1; Fyhn et al. 2010). The deformed sedimentary succession in the complex is of Early Cretaceous age, which is documented by biostratigraphical studies of outcrops and a $500 \mathrm{~m}$ deep well on the Phu Quoc island. A model for the thrust-fault deformation suggests that piggy-back basins were formed during displacement along the thrust faults. The translation was $3-8 \mathrm{~km}$ from east to west. The model is based on detailed structural analyses of 36 seismic sections that cover the Phu Quoc basin (Fig. 1). The main structural elements in the complex are flats and ramps with hanging-wall anticlines developed above the ramps. The crests of the hanging-wall anticlines occur as remnants of partially eroded structural highs. This paper describes the thin-skinned thrust-fault structures that form the basis for the interpretation of the concealed fold-belt complex in the Phu Quoc basin.

\section{Architectural framework of the fold belt}

Along the west coast of Vietnam folded and thrust-deformed Mesozoic and Palaeozoic sedimentary rocks form a N-Sstriking fold belt referred to as the Kampot fold belt (Fyhn et al. 2010). To the north the fold belt continues into a hilly area at the border between Vietnam and Cambodia, where it forms a mountain range. To the south, offshore the west coast of Vietnam, the fold belt is concealed below Neogene marine sediments.

From west to east the fold belt is divided into a distal, intermediate and proximal part (Fig. 1). The distal part is a frontal wedge that passes into the foreland about $100 \mathrm{~km}$ west of the Vietnam coast. The intermediate part is characterised by moderately folded, hanging-wall anticlines with thrust displacements in the order of a few kilometres. The transition from the intermediate to the proximal parts is located close to the Nam Du archipelago (Pedersen et al. 2009). Two interpreted, representative seismic sections have been selected to illustrate the architectural style in structural cross-sections perpendicular to the main trend of the thrustfault belt (Figs 2, 3).

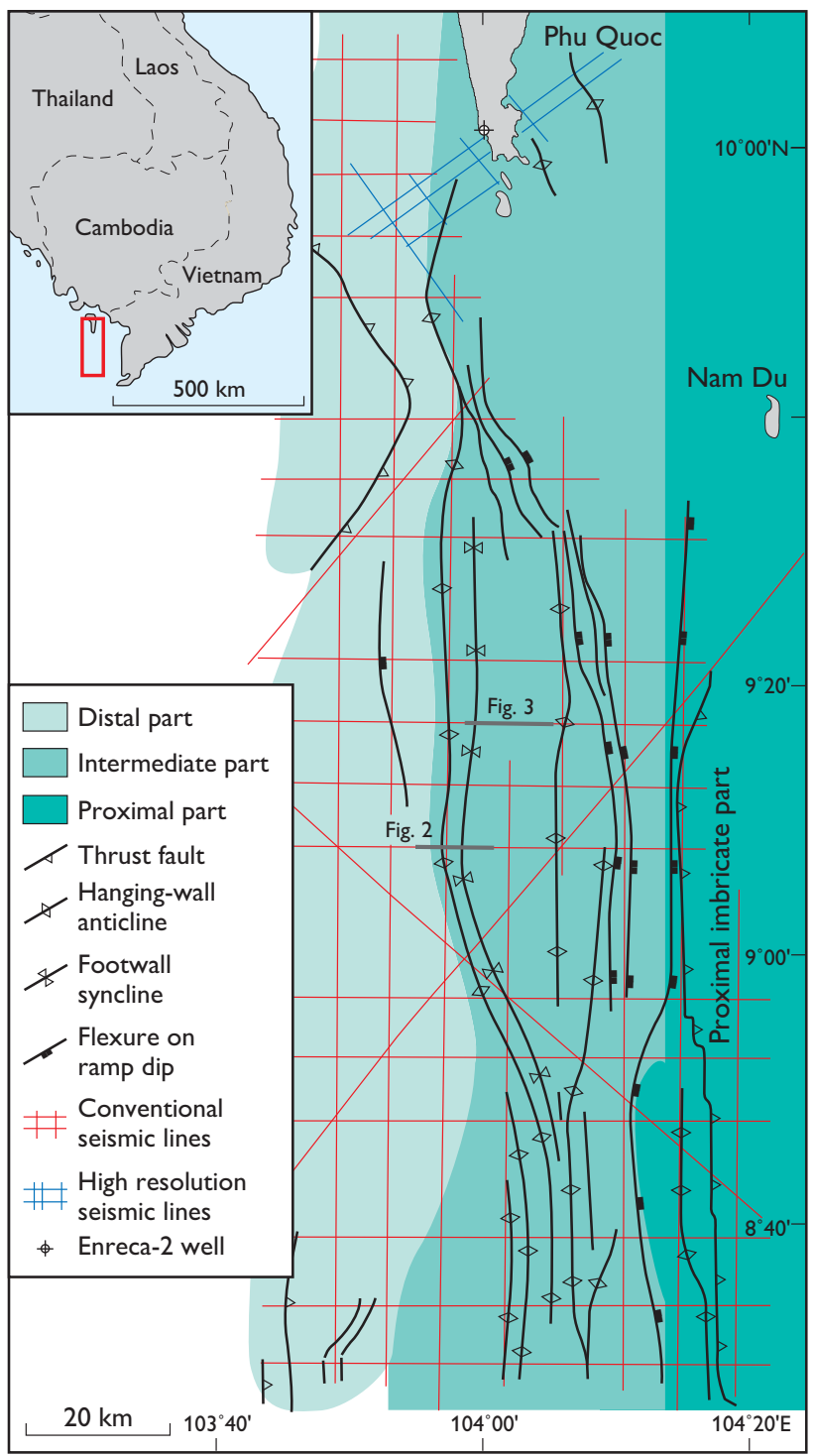

Fig. 1. Map of the study area off SW Vietnam, showing the seismic grid which formed the basis for the study of the Phu Quoc basin. On the map the main structural elements are shown with the trends of anticlines and thrust faults interpreted from the seismic sections. The location of the $500 \mathrm{~m}$ deep well ENRECA-2 on the Phu Quoc island and the position of the two cross-sections in Figs 2 and 3 representing the distal and the intermediate parts of the deformation complex are also shown. The inset map shows the location of the investigated area in SE Asia. 

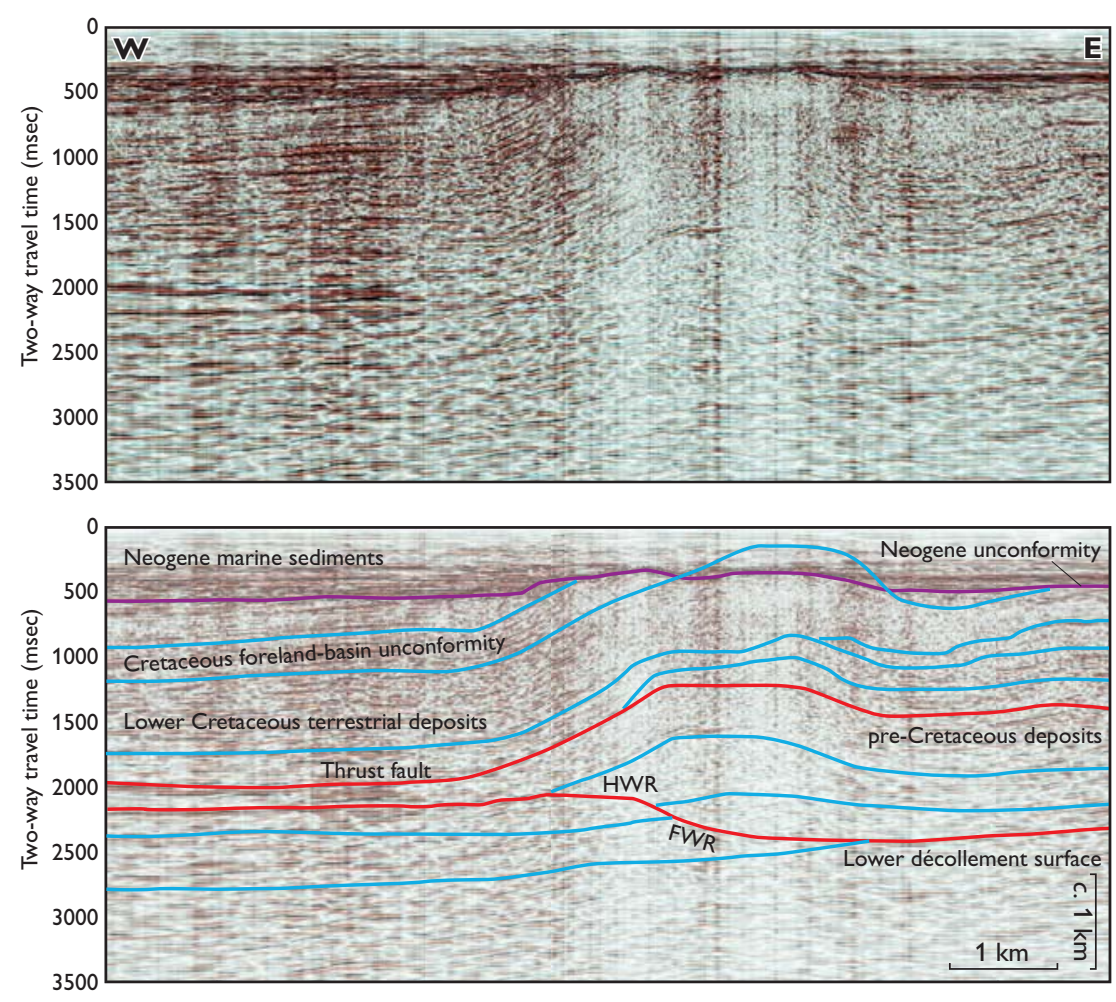

Fig. 2. Seismic section representing the distal part of the tectonic complex. In the western part of the cross-section the most distally appearing hanging-wall anticline is seen, and to the west the almost planar horizontal bedding extends into the foreland basin. Beds in the youngest Phu Quoc unit onlap the moderately dipping beds on the western limb of the hanging-wall anticline, and these beds as well as the top of the hanging-wall anticline are truncated by the Neogene unconformity. HWR: hanging-wall ramp, FWR: footwall ramp. Blue lines: prominent bedding surfaces. Red lines: thrust faults. Purple line: the main Neogene unconformity that truncates the structures in the tectonic complex. For location see Fig. 1.

\section{The distal part of the tectonic complex}

The distal part of the complex passes gradually into the undeformed foreland where almost horizontally bedded Cretaceous sediments occur, which are separated from overlying Neogene marine sediments by a distinct unconformity. Thrust-faults dipping $<2^{\circ}$ are found from the foreland towards the intermediate part. A number of minor ramps are present until the main décollement zone passes into a deeper level along a moderately dipping ramp, above which the westernmost, major hanging-wall anticline is seen (Fig. 2).

The main décollement zone is located below $2.5 \mathrm{~km}$ of sediments in the distal area, west of the foreland-near, hanging-wall anticline. The ramp takes the décollement zone down to $3 \mathrm{~km}$ below surface. At this depth the resolution of the seismic data becomes low, so no further interpretations are carried out. The hanging-wall anticline is relatively flat-topped, which corresponds well with a model for hanging-wall anticlines where the displacement is about half the thickness of the thrust-faulted sedimentary rock unit (Pedersen 2006). The western limb of the hanging-wall anticline $\operatorname{dips} c .25^{\circ} \mathrm{W}$, and the uppermost depositional unit below the Neogene unconformity on-laps the dipping limb. The beds in this unit are gently tilted towards the west due to the main, gentle dip of the depositional wedge in the frontal part of the thrust system. Therefore this uppermost depositional unit may be regarded as a piggy-back basin, which was formed during the translation of the frontal part of the thrust-fault complex. Interpretations of the seismic sections north of the presented cross-section show additional examples of piggyback basins. The most important of these is a basin found south-east of the Phu Quoc island. It formed between two hanging-wall anticlines during their fold and translation development. In addition, we have interpreted the gently deformed Lower Cretaceous deposits that were penetrated by the ENRECA-2 well on the Phu Quoc island to continue into the deformed succession offshore. In our tectonic model the environment surrounding Phu Quoc island is regarded as located at the transition from the distal to the intermediate part of the tectonic complex.

\section{The intermediate part of the tectonic complex}

Two or more levels of thrust faults with flats and ramps have developed in the intermediate part of the complex (Figs 1, 3). The number of ramps increases eastwards, which leads to an increasing number of hanging-wall anticlines, some of which are interpreted to have developed into antiformal stacks. The appearance of duplex structures initially lifted the top of the tectonic complex to a higher level. However, this is only recognised as a deeper level of erosion into the tectono-stratigraphic units. The displacement increases to $3-8 \mathrm{~km}$ resulting in some variation in the structural style of 
Fig. 3. Seismic section representing the intermediate part of the tectonic complex. This part is characterised by increasing numbers of hangingwall anticlines and thrust faults. The upper thrust fault constitutes an upper flat to the west, an upper footwall ramp (FWR) that connects the upper flat to an intermediate flat, and a lower footwall ramp that continues into the lower flat to the east. Each footwall ramp corresponds to a hanging-wall anticline above a displaced hangingwall ramp (HWR). Due to the presence of two footwall ramps a prominent syncline developed between the two hanging-wall anticlines. Blue lines: prominent bedding surfaces. Red lines: thrust faults. Purple line: the main Neogene unconformity that truncates the structures in the tectonic complex. For location see Fig. 1.
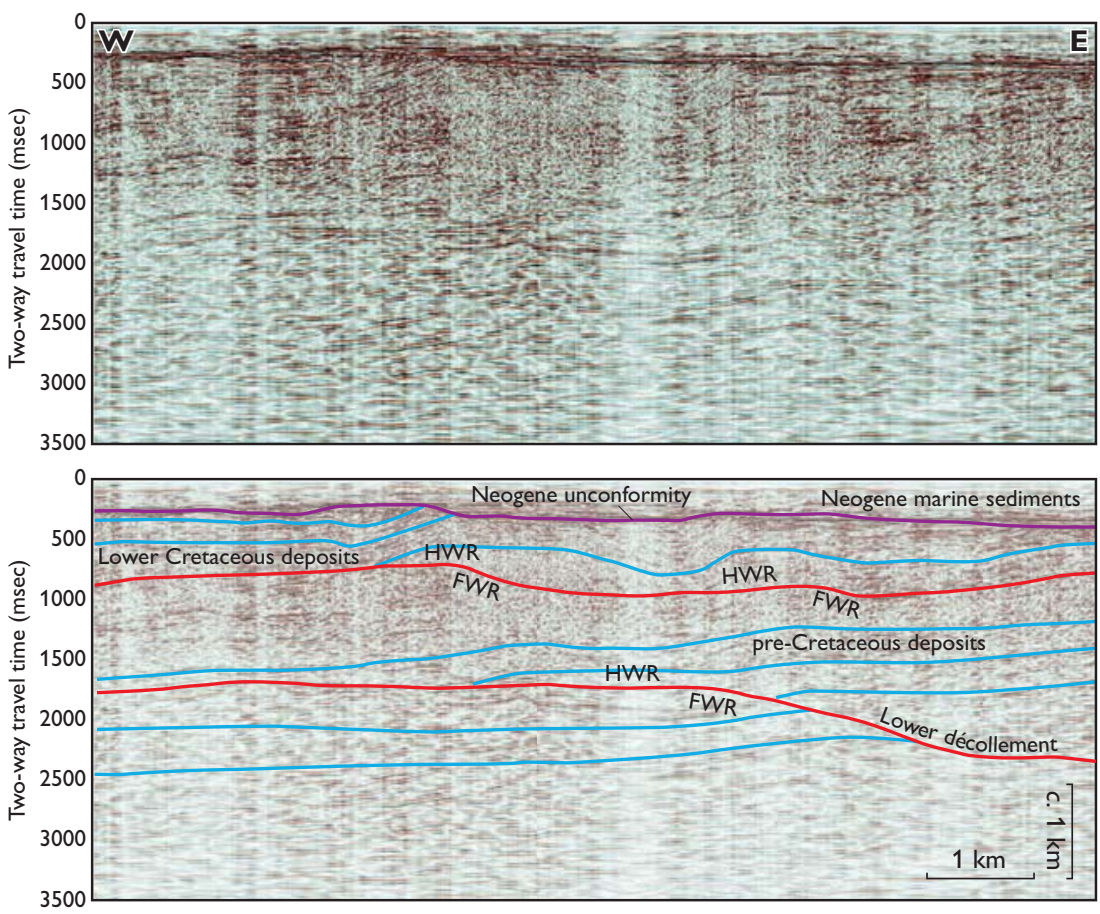

the hanging-wall anticlines. At the transition from the intermediate to the proximal part, erosional remnants of the hanging-wall anticlines are preserved as scattered islands rising a few hundred metres above sea level. The easternmost island in the Nam Du archipelago provides an example of this. On this island the thrust deformation elevated Permian rhyolitic hyaloclastics to a surface-near position (Pedersen $e t$ al. 2009).

\section{The proximal part of the tectonic complex}

The proximal part of the tectonic complex is only covered by seismic data only in the south-eastern part of the study area (Fig. 1). Here steeply dipping imbricate structures with 200-500 m thick thrust sheets occur. The depth to the décollement zone is more than $3 \mathrm{~km}$. Onshore the imbricate structures in the proximal part are exposed in the mountain range at the border between Vietnam and Cambodia. In this area the general dip of the thrust sheets is about $30^{\circ}$, and the deformed sedimentary rocks comprise Upper Palaeozoic sandstones and shales, Permian carbonates and Triassic sandstones, arkoses and conglomerates. In the thrust-fault zones, shearing and low-grade metamorphism have altered the sediments with recrystallisation of albite and formation of chlorite and biotite, corresponding to lower to medium greenschist facies. No minerals indicating higher metamorphic grades have been recognised. One of the small islands c. $50 \mathrm{~km}$ north-north-east of Nam Du is located in the proximal part. On this island, Permian carbonates are thrustfaulted over Jurassic shales and sandstones. A granitic plug occurs in the middle part of the island and granitic sills have intruded the Jurassic succession. The intrusions are of lower Cretaceous age (Pedersen et al. 2009).

Cretaceous granitic intrusions occur on the mainland east of the proximal part of the tectonic complex. They form a Cretaceous magmatic arc in the hinterland zone of the Kampot fold belt (Fyhn et al. 2010). The intrusive age of the granites is based on radiometric dating, and the dating of the uplift and erosion is based on fission-track studies that indicate exhumation during the Eocene (Fyhn et al. 2010).

\section{Discussion}

The timing of the deposition of the basin fill and the deformation of the Phu Quoc basin are addressed by the tectonic model. The structural interpretation of the thrust-fault structures implies that the piggy-back basins formed in the Cretaceous, which in turn suggests that the deformation started in the Cretaceous. However, according to the apatite fission-track analysis the sedimentary rocks in the Phu Quoc basin and the Kampot fold belt were buried to a depth where the temperature exceeded $100^{\circ} \mathrm{C}$ (Fyhn et al. 2010). This indicates burial below $2-3 \mathrm{~km}$ of sediments that were entirely eroded away in the early Eocene when the main exhumation 
of the region occurred (Fyhn et al. 2010). It is suggested that the compressional deformation was caused by subduction of the westernmost part of the Pacific Ocean plate (Metcalfe 1996). Erosion of the up-thrust, pre-Cretaceous rock units in the Kampot fold belt supplied sediments for the Cretaceous deposits in the Phu Quoc basin. The progressing compression led to deformation of the proximal part of the basin. A crosssection of the tectonic complex indicates a $200 \mathrm{~km}$ wide zone and the shortening of the complex is roughly estimated to be $50 \%$. Assuming a compressional orogenic translation in the order of $5 \mathrm{~cm} / \mathrm{y}$, the deformation lasted $c .4$ million years. Following the deformation, granites were intruded into the fold belt as the subducted sedimentary rocks below the fold belt began to melt. The age of the intrusions corresponds with the Cretaceous deformation in the distal part of the tectonic complex. The crucial issue is to understand the mechanism that caused uplift in the Eocene and subsidence in the Neogene. We suggest that the subducted slab with a top layer of granitic composition was less dense than the base of the overlying lithosphere, and that this could cause a regional but orogenically passive uplift. The uplift was followed by Eocene-Miocene erosion and denudation before the raised granitic lithosphere cooled, which led to the Neogene subsidence that created new accommodation space in the area above the Phu Quoc basin.

\section{Conclusion}

The deposits in the Phu Quoc basin off south-west Vietnam were affected by a Late Mesozoic orogeny. The tectonic complex at Nam Du archipelago is characterised by thin-skinned thrust-fault deformation with a distal part to the west, an intermediate part around the Nam Du archipelago, and a proximal part, which includes a hilly area in the onshore part of the Kampot fold belt. The hinterland of the tectonic complex includes a magmatic arc represented by granitic plutons exposed in the south-western part of Vietnam.

The orogenic deformation of the complex is interpreted to be of early-middle Cretaceous age. The complex was successively buried by a more than two kilometres thick package of sediments that was removed by erosion during uplift in the early Eocene. Finally subsidence in the Neogene resulted in sedimentation that covered the Mid-Tertiary unconformity.

\section{Acknowledgements}

We thank Vietnam Petroleum Institute and PetroVietnam for permission to use the commercial seismic data and permission to publish Figs 2 and 3. The company Landmark is thanked for a university grant to the Department of Geography and Geology at Copenhagen University. The ENRECA programme of DANIDA is thanked for financial support.

\section{References}

Fyhn, M., Pedersen, S.A.S., Boldreel, L.O., Nielsen, L.H., Green, F.P., Dien, P.T., Huyen, L.T. \& Frei, D. 2010: Palaeocene - early Eocene inversion of the Phuquoc-Kampot Som basin: SE Asian deformation associated with the suturing of Luconia. Journal of the Geological Society (London) 167, 281-295.

Metcalfe, I. 1996. Pre-Cretaceous evolution of SE Asian terranes. In: Hall, R., Blundell, D. (eds.): Tectonic Evolution of Southeast Asia. Geological Society Special Publication (London) 106, 97-122.

Pedersen, S.A.S.2006: Strukturer og dynamisk udvikling af Rubjerg Knude Glacialtektoniske Kompleks, Vendsyssel, Danmark. Geologisk Tidsskrift 2006, 1, 46 pp.

Pedersen, S.A.S., Fyhn, M. Dien, P.T., Boldreel, L.O., Nielsen, L.H., Green, F.P., Huyen, L.T. \& Mai, L.C. 2009: Structural geology of the Nam Du island and neighbouring areas in the Phu Quoc basin, SW Vietnam. Danmarks og Grønlands Geologiske Undersøgelse Rapport 2009/7, 47 pp. 